\title{
ASSOCIATION OF SPECIAL LIBRARIES \\ ARBEITSGEMEINSCHAFT DER SPEZIALBIBLIOTHEKEN
}

The eighteenth meeting of the Association of Special Libraries of the Federal Republic of Germany will take place in Aachen March 10-14, 1981.

For further information, contact: Näheres über:

Zentralbibliothek der Kernforschungsanlage Jülich

Frau Dr. Schneider

Postfach 13

D-5170 Jülich

$B R D$

\section{INTERNATIONAL MONETARY FUND \\ LAW LIBRARY \\ CURRENT ACCESSIONS LIST}

In the August 1980 issue of the journal (Vol. 8, No. 4, p. 173) we described the accessions list issued by the International Monetary Fund Law Library.

Eliana D. Prebisch, the Law Librarian, has now written to us in order to point out several errors in our note. The correct title of the list is "Current Accessions," and the address of the International Monetary Fund is 700 19th Street, N.W., Washington, D.C. 20431. The high bibliographic quality of the list remains unaltered.

\section{NEW INCOTERMS}

The International Chamber of Commerce (ICC) has published a new version of Incoterms which define the rights and obligations of parties in international export and import transactions and establish mutually fair conditions in such transactions. The revision (1980) represents a considerable expansion of the original text, and it takes into account the evolution of advanced transport techniques and modern international trade practices. 
In conjunction with the Incoterms 1980, the ICC has also published a Guide to Incoterms which illustrates with practical examples the circumstances in which each provision of the Incoterms applies and what the consequences of its application are.

In the United States, these publications are available from:

ICC Publishing Corporation, Inc.

1212 Avenue of the Americas

New York, New York 10036

Incoterms 1980 is priced at U.S. \$5.00, and Guide to Incoterms at U.S. $\$ 8.75$.

\section{SURVEY OF SUBSCRIPTION COSTS \\ TO CANADIAN LEGAL PUBLICATIONS}

As reported in the May-July 1980 (Vol. 5, No. 5, N.S.) issue of the Canadian Association of Law Libraries Newsletter, costs of Canadian legal publications keep climbing at a rate parallel to that of many other countries. Prepared by Pat LaVac, University of British Columbia, at the request of Frank Winter, Chairman of the C.A.L.L. Statistics Committee, the report contains 1979 subscription rates of some 250 Canadian legal serials.

The comparative costs for 1978 and 1979 are of special interest:

Comparative Costs and Percentages Increase FOR YEARS

1978-1979

1978

1979

Number

Number Average Increase

of Average of Unit Per Percentage

Titles Unit Cost Titles Cost Unit Increase

Journals

$61 \quad 22.18$

$68 \quad 25.22 \quad 3.04$

$13.71 \%$

Looseleaf

Services

$75 \quad 100.45$

Reports

$32 \quad 64.57$

Statues

$29 \quad 22.90$

Miscellaneous

$41 \quad 33.85$

$\begin{array}{lr}82 & 107.10 \\ 33 & 67.00 \\ 31 & 26.84 \\ 42 & 40.40\end{array}$

6.65

$6.62 \%$

$2.43 \quad 3.76 \%$

$3.94 \quad 17.21 \%$

$6.55 \quad 19.35 \%$

Overall average increase : $12.13 \%$ 